\title{
MODERNITAS KYAI DAN IMPLIKASINYA TERHADAP PENDIDIKAN KEWIRAUSAHAAN DI PONDOK PESANTREN
}

\author{
Agus Eko Sujianto \\ STAIN Tulungagung \\ Email: ae_stainta@yahoo.co.id
}

\section{Abstract}

This study was developed from the results of in-depth research that aims to explain the contribution modernity of Kyai and their implications for entrepreneurship education in boarding schools (Pontren). The research approach used is a quantitative approach on the Boarding School Cooperatives (Koppontren) in Tulungagung District. The results showed that modernity indicated with the attitudes of Kyai with individual characteristics of modernity can increase the performance of Koppontren. That is, if a Kyai has attitudes and performs activities that lead to the advancement either for himself or other people included Koppontren, the existence of Koppontren can be enjoyed by the members

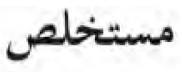

وقد أنشئت هذه الدراسة من نثائج البحث المتعمق، التي يشرح لنا عن مساهمة كياهي

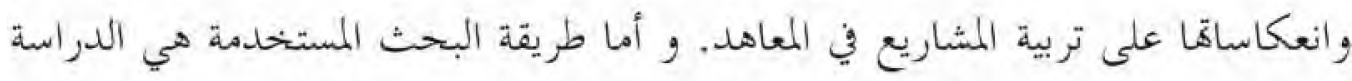

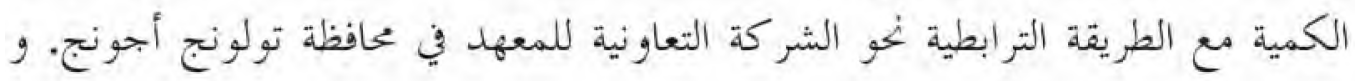

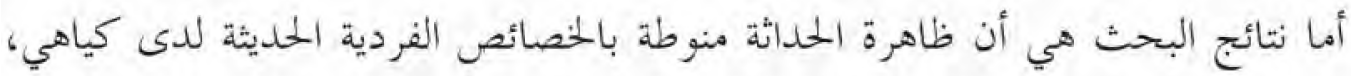

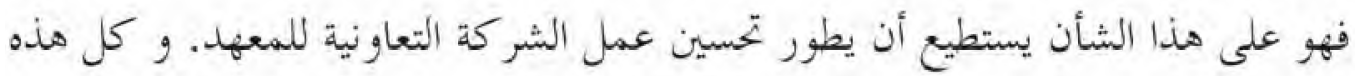
الأحوال يتحقق إذا كان كياهي عنده المواقف و قدرة على أداء الأنشطة التي تثودي

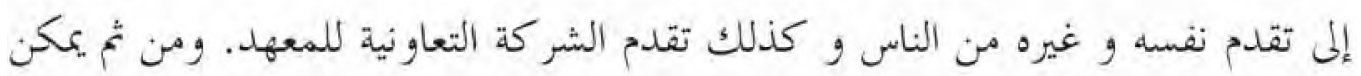

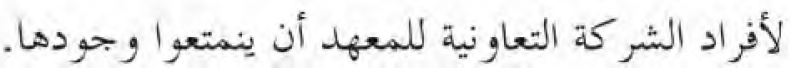

Keywords: Modernitas, Pendidikan, Kewirausahaan, Kinerja, Koppontren 


\section{A. Pendahuluan}

Dalam mewujudkan sumber daya manusia (SDM) yang berkualitas yaitu jujur dan tangguh dalam menghadapi tantangan zaman yang dalam waktu bersamaan harus menjadi insan yang taat menjalankan ajaran agama, peran Pontren dalam masyarakat sangat besar, terutama pada akar rumput. Oleh karena itu, proses modernisasi masyarakat dapat berjalan cepat apabila Pontren mendapat peran yang proporsional.

Studi ini menggunakan istilah Pontren dalam mendeskripsikan pondok pesantren, mengingat dalam Pontren terdapat Koppontren. Pemilihan kata Pontren ini dimaksudkan untuk menyesuaikan dengan kata Koppontren yang selama ini berkembang di masyarakat. Sedangkan pembahasan mengenai Koppontren didasarkan pada pertimbangan bahwa Koppontren merupakan salah satu unit usaha di lingkungan Pontren dan menjadi wahana bagi para santri untuk berlatih berwirausaha.

Pendidikan Pontren dalam menghadapi era global, pada awalnya terlihat enggan dan tidak secara total menerima perubahan sehingga tercipta kesenjangan antara Pontren dengan dunia luar. Kesan tertutup ini tidak berlangsung lama, karena secara bertahap Pontren bersikap akomodatif dan melakukan pembenahan untuk kemudian menemukan pola yang cukup tepat guna menghadapi perubahan yang kian cepat dan berdampak luas.

Hasil penelitian menunjukkan bahwa, laju perubahan menyentuh segala aspek masyarakat tidak terkecuali Pontren untuk kembali mempertanyakan mengenai keberadaan tradisi yang selama ini dimilikinya. Pada dasarnya keegoisan Pontren dalam memelihara tradisi yang dimilikinya akan memisahkan dunia Pontren dengan masyarakat serta mengancam eksistensi Pontren itu sendiri, karena untuk saat ini masyarakat lebih condong pada hal-hal yang bersifat rasional. Berdasarkan kenyataan dilapangan, beberapa Pontren menerapkan prinsip "al-muhafadzatu 'ala al-qodim wa al-akhdzu bi al jadid al-aslah", yakni melestarikan tradisi lama yang baik dan mengambil hal baru yang lebih baik untuk merespon perubahan. Berdasarkan prinsip ini Pontren melakukan pengkombinasian antara tuntunan perubahan dan tradisi yang selama ini dimilikinya. ${ }^{1}$

1 Umi Najikhah Fikriyati, Tradisi Pesantren Ditengah Perubahan Sosial (Studi Kasus Pada Pondok Pesantren Al-Munawwir Krapyak Yogyakarta), Penelitian, (Yogyakarta: UIN Sunan Kalijaga, 2009), hal. 56. 
Pentingnya perubahan yang lebih baik ini menunjukkan bahwa eskalasi perubahan sosial dan budaya yang terjadi sepanjang kehidupan manusia menjadikan perubahan sebagai keniscayaan yang tidak bisa dielakkan. Pontren sebagai 'institusi budaya' yang lahir atas prakarsa dan inisiatif tokoh masyarakat yang bersifat otonom, juga tak luput dari terpaan perubahan tersebut. Pada awalnya Pontren memposisikan diri dalam kapasitas sebagai institusi pendidikan dan keagamaan, kemudian berkembang dan melakukan reposisi seiring perubahan-perubahan sosial yang terjadi. ${ }^{2}$

Dalam studi ini, bentuk tanggung jawab Pontren terhadap perubahan tersebut adalah dengan diterapkannya pendidikan berbasis kompetensi, yaitu dengan semakin banyak memasukkan keterampilan secara nyata dengan dasar pendidikan kewirausahaan atau enterpreneurship kepada peserta didik (santri). ${ }^{3}$ Dalam konteks sosiologis (ta'rif istilahi), santri bermakna "setiap orang Islam yang relatif taat dalam menjalankan ajaran Islam” baik alumnus Pontren atau bukan.

Santri yang dimaksud dalam studi ini yaitu siswa yang belajar di Pontren dan digolongkan kepada dua kelompok: (1) santri mukim, yaitu para siswa yang datang dari tempat-tempat yang jauh yang tidak memungkinkan pulang ke rumahnya setiap hari, maka mereka tinggal di Pontren dan memiliki kewajiban-kewajiban tertentu dan (2) santri kalong, yaitu para siswa yang berasal dari daerah sekitar yang memungkinkan mereka pulang setiap hari ke tempat tinggal masing-masing setelah aktifitas belajar mengajar berakhir.

Dengan pendidikan kewirausahaan diharapkan bisa membekali santri dengan berbagai kemampuan sesuai dengan tuntutan zaman, terutama berkaitan dengan kebutuhan masyarakat dan dunia kerja. Pendidikan adalah kehidupan, untuk itu kegiatan belajar harus dapat membekali santri dengan kecakapan hidup (life skill atau life competency) yang sesuai dengan lingkungan kehidupan dan kebutuhan santri.

2 Sahlawi, Pondok Pesantren dan Perubahan Sosial (Strategi Adaptasi Pondok Pesantren Sidogiri dalam Menghadapi Perubahan Sosial), Tesis, (Surabaya: Universitas Airlangga, 2006), hal. 43.

3 Nurcholis Madjid menyebutkan bahwa santri, berasal dari kata sastri (sansekerta) yang berarti melek huruf, dikonotasikan dengan santri adalah kelas literary, pengetahuan agama dibaca dari kitab berbahasa Arab dan diasumsikan bahwa santri berarti juga orang yang tahu tentang agama (melalui kitab-kitab) dan paling tidak santri bisa membaca Al-Qur'an, sehingga membawa kepada sikap lebih serius dalam memandang agama. Perkataan santri juga berasal dari bahasa Jawa cantrik yang berarti orang yang selalu mengikuti seorang guru kemana guru pergi menetap (ingat pada pewayangan), tentu dengan tujuan dapat belajar dari guru mengenai suatu keahlian. Cantrik dapat diartikan juga orang yang menumpang hidup atau ngenger (Jawa). Termasuk orang yang datang menumpang dirumah orang lain yang mempunyai sawah dan ladang untuk ikut menjadi buruh tani juga disebut santri, tentu juga berasal dari perkataan cantrik. 
Sedangkan bentuk praktik keterampilan dan pendidikan kewirausahaan santri ini adalah Koppontren. Koppontren merupakan lembaga ekonomi yang berada di lingkungan Pontren, dan menjadi media bagi santri untuk melakukan praktik kerja, sehingga terdapat keseimbangan pola pendidikan agama dan pendidikan kewirausahaan. Sebagai unit bisnis di lingkungan Pontren, keberadaan Koppontren mendapat dukungan dari pemerintah.

Dukungan tersebut dalam bentuk: (1) Undang-Undang Republik Indonesia Nomor 25 Tahun 1992 tentang Perkoperasian; (2) Keputusan Bersama antara Menteri Koperasi (Nomor: 197/MJKPTSIIX/1985), Menteri Agama (Nomor: 64/TAHUN 1985) dan Ketua Umum Majelis Ulama Indonesia (Nomor: 490/MUI/VII/1985) tentang Pelaksanaan Pembinaan dan Pengembangan Koperasi dilingkungan Lembaga Dakwah dan Lembaga Pendidikan Agama dan (3) Keputusan Bersama Menteri Pertanian Nomor: 346/KPTS/HK.050/6/1991 dan Menteri Agama (Nomor: 94 tahun 1991) tentang Pengembangan Agribisnis di Pontren.

Inti dari masing-masing produk hukum tersebut adalah: (1) UU 25/1992 merupakan ketentuan yang mengatur mekanisme perkoperasian secara umum tentang: a) landasan, asas dan tujuan, b) fungsi, peran dan prinsip koperasi, c) pembentukan, d) keanggotaan, e) perangkat organisasi, f) modal, g) lapangan usaha, h) SHU, i) pembubaran koperasi, j) lembaga gerakan koperasi, k) pembinaan dan 1) ketentuan peralihan; (2) Keputusan Bersama Menteri Koperasi, Menteri Agama dan Ketua Umum Majelis Ulama Indonesia berisi ketentuan tentang pelaksanaan pembinaan dan pengembangan koperasi di lingkungan lembaga dakwah dan lembaga pendidikan agama dilakukan secara terpadu dan (3) Keputusan Bersama Menteri Pertanian dan Menteri Agama berisi ketentuan tentang pendidikan Pontren agribisnis, dimana para santri tidak hanya dididik dengan ilmu keislaman secara mendalam melalui sumber aslinya, yakni kitab kuning (tafaqquh fi din) namun juga 'Bengkel Life Skill' yang tujuannya adalah untuk memperkuat basis ekonomi Pontren dalam rangka menjalankan visi dan misinya dibidang pendidikan dan pembinaan akhlak bagi para santri serta masyarakat di sekitarnya, dan untuk meningkatkan peran Pontren dalam pembangunan pertanian melalui pengembangan agribisnis di Pontren.

Selain tiga ketentuan di atas, UUD 1945 pasal 33 ayat 1 menyatakan bahwa perekonomian Indonesia disusun sebagai usaha bersama berdasar atas asas kekeluargaan. Kemudian didefinisikan bahwa koperasi adalah perkumpulan otonom dari orang-orang yang bersatu secara sukarela untuk memenuhi kebutuhan-kebutuhan 
dan aspirasi-aspirasi ekonomi, sosial dan budaya bersama melalui perusahaan yang mereka kendalikan secara demokratis. Sedangkan Koppontren sebagai salah satu jenis koperasi berasal dari anggota dan dinikmati oleh anggota, maka dalam operasionalnya dikendalikan oleh anggota. Koppontren dibentuk karena terdapat kebutuhan yang sama para santri, dengan demikian partisipasi mereka sangat diharapkan dan merupakan "ruh" atau jiwa dalam berkoperasi. Partisipasi anggota harus dipupuk untuk mewujudkan perekonomian yang sesuai dengan cita-cita luhur sebagaimana dideskripsikan dalam UUD 1945.

Terwujudnya partisipasi aktif anggota Koppontren menjadi cita-cita Koppontren dalam merealisir tujuan yang telah ditetapkannya. Tetapi untuk membangun partisipasi aktif anggota juga tidaklah mudah. Diperlukan upaya strategis dan keberpihakan dari semua pihak, baik pengurus maupun Kyai. Keberpihakan Kyai diperlukan mengingat keberadaan Koppontren di lingkungan Pontren, dimana Kyai sebagai pemilik, pengasuh dan pemimpin Pontren. Upaya strategis yang dimaksud adalah pembinaan perkoperasian kepada anggota Koppontren secara berkelanjutan.

Keberpihakan tidak sama dengan campur tangan. Keberpihakan lebih bersifat memotivasi Koppontren untuk dapat berkembang sesuai dengan kebutuhan anggotanya (santri). Sedangkan campur tangan lebih bersifat mengedepankan kepentingan seorang motivator, sehingga pembentukan Koppontren bersifat top down. Kepemimpinan uswatun hasanah (tauladan) dari Kyai dalam rangka membangun manusia Indonesia menyongsong kepemimpinan masa depan sangat dibutuhkan. Wujud kepemimpinan tauladan ini adalah dengan keberpihakan Kyai pada Koppontren, yaitu dengan memotivasi, memberi arahan untuk meningkatkan kinerja Koppontren. Tidak selamanya koperasi (termasuk Koppontren) hidup dibawah bayang-bayang dan bantuan dari pemerintah. Kyai yang dalam kesehariannya selalu "bersentuhan" dengan santri sebagai anggota Koppontren, sangat menentukan keberhasilan Koppontren.

Kyai mempunyai peran strategis dalam memajukan Koppontren. Sedangkan yang menjadi tantangan bagi para Kyai pengasuh Pontren dalam urusan ekonomi adalah memperbesar jumlah Koppontren dan anggotanya. ${ }^{4}$ Beberapa studi kasus, misalnya pendiri Koppontren Sidogiri mengadaptasi jiwa koperasi "dari anggota,

4 Subiakto Tjakrawerdaja, dalam Suara Pembaruan Online. 5 November 1996, "Kebijaksanaan pengembangan dan pembinaan koperasi pondok pesantren", dikutip dari http://www.hamline.edu/ apakabar/basisdata/1996/11/08/0010.html, accessed 7 Desember 2007. 
oleh anggota dan untuk anggota" menjadi "dari santri, oleh santri dan untuk santri”. Karena itulah, modal Koppontren dihimpun dari para santri, dikelola oleh santri dan manfaat atau keuntungannya juga kembali pada santri. ${ }^{5}$ Demikian halnya pada Pontren Darussalam Gontor pada masa kepemimpinan generasi ketiga, Gontor tidak banyak didatangi santri serta kegiatan pendidikan dan pengajaran mulai memudar. Untuk itu, diperlukan nilai-nilai yang dijadikan jiwa oleh seluruh kehidupan di Pontren dengan merumuskan nilai-nilai "Panca Jiwa Pondok" yaitu: (1) jiwa keikhlasan; (2) jiwa kesederhanaan; (3) jiwa berdikari; (4) jiwa ukhuwah diniyyah dan (5) jiwa bebas. ${ }^{6}$

Pemikiran inilah yang menjadi dasar bahwa wawasan Kyai sebagai pengasuh, pemilik sekaligus guru di lingkungan Pontren sangat mewarnai perkembangan dan keberhasilan Koppontren. Sebagai tokoh sentral untuk memotivasi tingkat partisipasi anggota, peran dan kepedulian Kyai dalam bentuk melindungi, membimbing, mendorong serta memfasilitasi sangat strategis dalam memajukan Koppontren yang ditunjukkan dengan membaiknya kinerja Koppontren dari periode ke periode.

\section{B. Modernitas Kyai}

Modernitas berasal dari kata modernity, yang diartikan sebagai suatu proses yang sangat manusiawi yang tidak dapat dihindarkan lagi. ${ }^{7}$ Modernitas juga dinyatakan sebagai fenomena yang tidak dapat dihindarkan lagi yang berpengaruh pada perubahan social behaviour (perilaku sosial), sehingga secara tidak langsung mengubah self-identity. ${ }^{8}$

Berdasar pemikiran tersebut, modernity merupakan suatu istilah yang mengacu pada era modern. Sedangkan posisi dan peran Kyai di Pontren sangat penting dalam pembuatan kebijakan, sehingga Kyai diharapkan dapat membuat suatu strategi kreatif dalam adaptasi sosial dan kultural yang pada waktunya Pontren dapat memperoleh inspirasi dan menjadi katalisator (pembawa perubahan) dari transformasi budaya.

5 M.S.Bakhri, Kebangkitan Ekonomi Syariah di Pesantren: Belajar dari Pengalaman Sidogiri. (Jakarta: Cipta Pustaka Utama, 2004), hal. 38.

6 Basuki, Pesantren, Tasawuf dan Hedonisme Kultural (Studi Kasus di Pondok Modern Darussalam Gontor) dalam Quo Vadis Islamic Studies in Indonesia? (Current Trends and Future Challenges). Cetakan Pertama. (Jakarta: DIKTIS Departemen Agama RI, 2006), hal. 67.

7 M. Dehaene, "Survey and assimilation of a modernist narrative in urbanism", The journal of architecture. Vol.7 No.1, (Spring 2002), hal. 36.

8 Anthony Giddens, "Modernity and Self Identity", dikutip dari http://www.theory.org.uk/ giddens4.htm, accessed 6 Maret 2008. 
Relevansinya dengan Koppontren dalam kapasitasnya sebagai pemilik, pengelola dan pengasuh Pontren, peran Kyai dalam memajukan Koppontren ditengah arus globalisasi sekarang ini dituntut untuk responsif dengan modernisasi. Abdurrahman Wahid, ${ }^{9}$ menjelaskan, Hiroko Horikoshi dalam disertasinya menunjukkan bahwa Kyai bukanlah bendungan tinggi yang memiliki peranan pasif, melainkan justru menjadi "agen pembaharuan".

Jadi, modernitas Kyai sangatlah penting untuk menjalankan perahu Pontren berikut lembaga-lembaga yang berada di dalamnya termasuk Koppontren. Berdasar perintah Nabi Muhammad SAW berikut sangatlah populer: "Bekerjalah untuk kehidupan duniawimu seolah-olah kamu akan hidup untuk selamanya, ..." Perintah Nabi ini mengisyaratkan tentang perintah bekerja, dalam hal ini bekerjasama dalam konsep ekonomi Koppontren.

Wawasan Kyai yang ditunjukkan dengan kemodernan Kyai dalam menyikapi perubahan lingkungan ekternal Koppontren dapat memotivasi anggota Koppontren untuk berpartisipasi aktif dalam koperasi yang pada akhirnya dapat membantu dalam memajukan Koppontren sebagai salah satu lembaga bisnis di lingkungan Pontren. Sedangkan untuk mengukur modernitas mengalami perkembangan dan perubahan namun ada pula yang bersifat universal berlaku sepanjang zaman. Iskandar ${ }^{10}$ menyatakan bahwa indikator modernitas diantaranya adalah semangat pembaruan (inovasi), rasional, kritis, a-historis serta antisimbol. Dalam studi yang lain disebutkan bahwa, untuk mengevaluasi modernitas didasarkan pada: (1) subjective efficacy; (2) terbuka untuk berubah dan (3) kecenderungan untuk merencanakan.

Dalam studi ini, indikator modernitas Kyai diturunkan dari 12 indikator modernitas individulnya Inkeles dan Smith ${ }^{11}$ yaitu: terbuka terhadap pengalaman baru, siap terhadap perubahan sosial, fleksibel dalam menerima pendapat yang berbeda, menerima opini berdasar fakta-fakta dan informasi, kecenderungan untuk merencanakan, wawasan tentang bisnis.

9 Abdurrahman Wahid, "Memahami Peran Budaya Pesantren", dikutip dari HTTP:// WWW.PONDOKPESANTREN. NET/PONPREN/INDEX.PHP?OPTION=COM_CONTENT\&TASK=VIEW\&ID $=51$, accessed 16 Maret 2008.

10 M.S.B. Iskandar, "Tradisionalitas dan Modernitas Tipologi Arsitektur Masjid", DIMENSI TEKNIK ARSITEKTUR. Vol. 32, No. 2, Desember, (Surabaya: Universitas Kristen Petra, 2004), hal. 110-118.

11 Alex Inkeles dan D.H. Smith, Becoming Modern, (Cambridge: Harvard University Press, 1974), hal. 17. 
Berdasar pengamatan mendalam dalam bentuk penelitian pada unit analisis yaitu Koppontren di Kabupaten Tulungagung menyatakan bahwa, indikator terbuka terhadap pengalaman baru diturunkan menjadi 2 deskriptor yaitu: menerima saran untuk kemajuan bersama serta menerima ide baru. Deskriptor yang pertama dideskripsikan oleh 2 item pernyataan. Untuk item Kyai menerima saran untuk kemajuan Koppontren, sebanyak 155 responden (48,4\%) mayoritas responden menjawab setuju. Hal ini menunjukkan bahwa responden setuju Kyai menerima saran untuk kemajuan Koppontren. Sedangkan item Kyai memotivasi saya untuk mengikuti kegiatan-kegiatan (mis.: seminar) terkait dengan Koppontren di luar Pontren, sebanyak 139 responden (43,4\%) mayoritas responden menjawab setuju. Hal ini menunjukkan bahwa Kyai memotivasi responden untuk mengikuti kegiatankegiatan (mis.: seminar) terkait dengan Koppontren di luar Pontren.

Deskriptor yang kedua dideskripsikan oleh 2 item pernyataan. Untuk item Kyai menerima kehadiran orang baru yang membawa perubahan Koppontren ke arah yang lebih baik, sebanyak 149 responden (46,6\%) mayoritas responden menjawab setuju. Hal ini menunjukkan bahwa responden setuju Kyai menerima kehadiran orang baru yang membawa perubahan Koppontren ke arah yang lebih baik.

Sedangkan item Kyai memotivasi saya untuk menjalin kerjasama dengan instansi terkait (mis.: Balai Latihan Kerja), sebanyak 127 responden (39,7\%) mayoritas responden menjawab setuju. Hal ini menunjukkan bahwa responden setuju, Kyai memotivasi responden untuk menjalin kerjasama dengan instansi terkait (mis.: Balai Latihan Kerja).

Indikator siap terhadap perubahan sosial diturunkan menjadi 2 deskriptor yaitu: memberi kesempatan untuk berkembang serta memperhatikan persoalanpersoalan yang dihadapi masyarakat. Deskriptor yang pertama dideskripsikan oleh 2 item pernyataan. Untuk item Kyai bersikap dinamis dalam menghadapi fakta perubahan terkait dengan Koppontren, sebanyak 156 responden (48,8\%) mayoritas responden menjawab setuju. Hal ini menunjukkan bahwa responden setuju Kyai bersikap dinamis dalam menghadapi fakta perubahan terkait dengan Koppontren. Sedangkan item Kyai responsif dengan perubahan terkait dengan Koppontren, sebanyak 140 responden (43,8\%) mayoritas responden menjawab setuju. Hal ini menunjukkan bahwa responden setuju Kyai responsif dengan perubahan terkait dengan Koppontren.

Deskriptor yang kedua dideskripsikan oleh 2 item pernyataan. Untuk item Kyai memberi arahan tentang perluasan produk Koppontren, sebanyak 127 
responden $(29,7 \%)$ mayoritas responden menjawab setuju. Hal ini menunjukkan bahwa responden setuju Kyai memberi arahan tentang perluasan produk Koppontren. Sedangkan item Kyai memberi kebebasan untuk memanfaatkan media pembelajaran terkait dengan Koppontren (mis.: majalah, koran, internet), sebanyak 142 responden $(44,4 \%$ ) mayoritas responden menjawab setuju. Hal ini menunjukkan bahwa responden setuju Kyai memberi kebebasan untuk memanfaatkan media pembelajaran terkait dengan Koppontren.

Indikator fleksibel dalam menerima pendapat yang berbeda diturunkan menjadi 3 deskriptor yaitu: (1) akomodatif terhadap perbedaan pendapat; (2) berpartisipasi aktif dalam setiap pertemuan dengan pengurus Koppontren dan (3) senantiasa mencari jalan keluar terhadap persoalan-persoalan yang dihadapi.

Deskriptor yang pertama dideskripsikan oleh 2 item pernyataan. Untuk item Kyai akomodatif terhadap perbedaan pendapat dalam Koppontren, sebanyak 132 responden $(41,3 \%)$ mayoritas responden menjawab kadang-kadang. Hal ini menunjukkan bahwa menurut responden, Kyai kadang-kadang akomodatif terhadap perbedaan pendapat dalam Koppontren. Sedangkan item Kyai menghargai pendapat anggota dalam forum Rapat Anggota Tahunan (RAT), sebanyak 111 responden (34,7\%) mayoritas responden menjawab kadang-kadang. Hal ini menunjukkan bahwa menurut responden Kyai kadang-kadang menghargai pendapat anggota dalam forum RAT.

Deskriptor yang kedua dideskripsikan oleh 1 item pernyataan. Untuk item Kyai berpartisipasi aktif dalam setiap pertemuan dengan pengurus Koppontren, sebanyak 121 responden $(37,8 \%)$ mayoritas responden menjawab kadang-kadang. Hal ini menunjukkan bahwa menurut responden Kyai kadang-kadang berpartisipasi aktif dalam setiap pertemuan dengan pengurus Koppontren. Sedangkan deskriptor yang ketiga dideskripsikan oleh 1 item pernyataan. Untuk item Kyai senantiasa mencari jalan keluar terhadap persoalan-persoalan yang dihadapi Koppontren, sebanyak 103 responden $(32,2 \%)$ mayoritas responden menjawab selalu. Hal ini menunjukkan bahwa menurut responden Kyai senantiasa selalu mencari jalan keluar terhadap persoalan-persoalan yang dihadapi Koppontren.

Indikator menerima opini berdasar fakta-fakta dan informasi diturunkan menjadi 3 deskriptor yaitu: (1) pengambilan keputusan didasarkan pada fakta-fakta; (2) pengambilan keputusan didasarkan pada informasi dan (3) tidak menerima opini secara hierarkis. Deskriptor yang pertama dideskripsikan oleh 1 item pernyataan, yaitu item Kyai dalam pengambilan keputusan terkait dengan Koppontren didasarkan pada fakta-fakta, sebanyak 151 responden (47,2\%) mayoritas 
responden menjawab setuju. Hal ini menunjukkan bahwa responden setuju, Kyai dalam pengambilan keputusan terkait dengan Koppontren didasarkan pada faktafakta.

Deskriptor yang kedua dideskripsikan oleh 1 item pernyataan, yaitu item Kyai dalam pengambilan keputusan terkait dengan Koppontren didasarkan pada informasi yang akurat, sebanyak 163 responden (50,9\%) mayoritas responden menjawab setuju. Hal ini menunjukkan bahwa responden setuju, Kyai dalam pengambilan keputusan terkait dengan Koppontren didasarkan pada informasi yang akurat.

Sedangkan deskriptor yang ketiga dideskripsikan oleh 2 item pernyataan. Untuk item Kyai menerima pendapat dari anggota Koppontren secara langsung, sebanyak 132 responden $(41,3 \%)$ mayoritas responden menjawab setuju. Hal ini menunjukkan bahwa responden setuju, Kyai menerima pendapat dari anggota Koppontren secara langsung. Kemudian item keputusan yang diambil oleh Kyai tidak bertentangan dengan Anggaran Dasar (AD) dan Anggaran Rumah Tangga (ART) Koppontren, sebanyak responden $(156 \%)$ mayoritas responden menjawab setuju. Hal ini menunjukkan bahwa responden setuju, keputusan yang diambil oleh Kyai tidak bertentangan dengan AD dan ART Koppontren.

Indikator kecenderungan untuk merencanakan diturunkan menjadi 1 deskriptor yaitu selalu membuat perencanan dalam urusan Koppontren. Deskriptor ini dideskripsikan oleh 4 item pernyataan. Item pertama, Kyai selalu membuat perencanan untuk kemajuan Koppontren, sebanyak 152 responden (47,5\%) mayoritas responden menjawab setuju. Hal ini menunjukkan bahwa responden setuju, Kyai selalu membuat perencanan untuk kemajuan Koppontren.

Item kedua, rencana yang dibuat Kyai sesuai dengan kondisi riil Koppontren saat ini, sebanyak 144 responden (45\%) mayoritas responden menjawab setuju. Hal ini menunjukkan bahwa responden setuju, rencana yang dibuat Kyai sesuai dengan kondisi riil Koppontren saat ini. Item ketiga, rencana yang dibuat Kyai dapat dijalankan oleh Koppontren, sebanyak 142 responden (44,4\%) mayoritas responden menjawab setuju. Hal ini menunjukkan bahwa responden setuju, rencana yang dibuat Kyai dapat dijalankan oleh Koppontren. Sedangkan item keempat, rencana yang dibuat Kyai relevan dengan unit usaha Koppontren, sebanyak 135 responden (42,2\%) mayoritas responden menjawab setuju. Hal ini menunjukkan bahwa responden setuju, rencana yang dibuat Kyai relevan dengan unit usaha Koppontren. 
Indikator wawasan tentang bisnis diturunkan menjadi 3 deskriptor yaitu: (1) jiwa Self Help; (2) berorientasi pada keseimbangan kepentingan duniawi dan ukhrawi serta (3) tidak menyandarkan kehidupannya kepada bantuan dan belas kasihan orang lain. Deskriptor yang pertama dideskripsikan oleh 1 item pernyataan, yaitu item Kyai memiliki wawasan tentang bisnis yang memadai, sebanyak 141 responden $(44,1 \%)$ mayoritas responden menjawab setuju. Hal ini menunjukkan bahwa responden setuju, Kyai memiliki wawasan tentang bisnis yang memadai.

Deskriptor yang kedua dideskripsikan oleh 2 item pernyataan. Item pertama, Kyai memberi kesempatan yang luas untuk pengembangan usaha Koppontren di lingkungan Pontren, sebanyak 150 responden (46,9\%) mayoritas responden menjawab setuju. Hal ini menunjukkan bahwa responden setuju, Kyai memberi kesempatan yang luas untuk pengembangan usaha Koppontren di lingkungan Pontren.

Item kedua, Kyai memberi fasilitas yang memadai terhadap Koppontren, sebanyak 132 responden (41,3\%) mayoritas responden menjawab setuju. Hal ini menunjukkan bahwa responden setuju, Kyai memberi fasilitas yang memadai terhadap Koppontren.

Deskriptor yang ketiga dideskripsikan oleh 1 item pernyataan, yaitu item Kyai memotivasi saya untuk melakukan bisnis dalam wadah Koppontren, sebanyak 138 responden $(43,1 \%)$ mayoritas responden menjawab setuju. Hal ini menunjukkan bahwa responden setuju, Kyai memotivasi responden untuk melakukan bisnis dalam wadah Koppontren.

\section{Pendidikan Kewirausahaan}

Pendidikan kewirausahaan dalam studi ini diidentifikasi dengan kinerja Koppontren. Pertimbangannya, keberadaan Koppontren merupakan bukti adanya pembelajaran kewirausahaan di Pontren walaupun secara implisit belum seluruhnya terakomodir dalam kurikulum. Sedangkan kinerja Koppontren merupakan jawaban dari berhasil atau tidaknya tujuan Koppontren yang telah ditetapkan dalam pemenuhan kebutuhan anggota, kepuasan anggota terhadap poduk dan layanan, kemampuan mempertahankan anggota lama, kemampuan menarik anggota baru, pencapaian visi serta pencapaian misi.

Indikator pemenuhan kebutuhan anggota diturunkan menjadi 2 deskriptor yaitu: koperasi mampu memenuhi kebutuhan anggota dan realisasi terhadap harapanharapan menjadi anggota koperasi. Deskriptor yang pertama ini dideskripsikan oleh 2 item pernyataan. Item selama ini Koppontren mampu memenuhi kebutuhan 
saya dalam hal penyediaan produk serta item selama ini produk Koppontren sesuai dengan keputusan yang telah disepakati dalam rapat anggota, masing-masing sebanyak 125 responden $(39,1 \%)$ dan 128 responden (40\%) mayoritas responden menjawab setuju. Hal ini menunjukkan bahwa responden setuju, Koppontren mampu memenuhi kebutuhan anggota dalam hal penyediaan produk serta produk Koppontren sesuai dengan keputusan yang telah disepakati dalam rapat anggota.

Deskriptor yang kedua dideskripsikan oleh 1 item pernyataan. Yaitu item selama ini saya mendapat pelayanan yang sama antara sesama anggota oleh Koppontren, sebanyak 132 responden (41,3\%) mayoritas responden menjawab setuju. Hal ini menunjukkan bahwa responden setuju, telah mendapat pelayanan yang sama antara sesama anggota oleh Koppontren.

Indikator kepuasan anggota terhadap produk dan layanan diturunkan menjadi 2 deskriptor yaitu: kepuasan anggota terhadap produk koperasi serta kepuasan anggota terhadap layanan koperasi. Deskriptor yang pertama ini dideskripsikan oleh 2 item pernyataan. Dalam hal ini item "selama ini produk yang dijual Koppontren dalam kondisi yang baik sehingga saya merasa puas serta item selama ini saya puas dengan keberadaan Koppontren di lingkungan Pontren”, masingmasing sebanyak 139 responden $(43,4 \%)$ dan 131 responden (40,9\%) mayoritas responden menjawab setuju. Hal ini menunjukkan bahwa responden setuju, produk yang dijual Koppontren dalam kondisi yang baik sehingga responden merasa puas serta responden puas dengan keberadaan Koppontren di lingkungan Pontren.

Sedangkan deskriptor yang kedua dideskripsikan oleh 1 item pernyataan, yaitu item selama ini layanan Koppontren kepada anggota sudah sesuai seperti halnya perusahaan-perusahaan non Koppontren, sebanyak 124 responden (38,8\%) mayoritas responden menjawab setuju. Hal ini menunjukkan bahwa responden setuju, layanan Koppontren kepada responden sudah sesuai seperti halnya perusahaan-perusahaan non Koppontren.

Indikator kemampuan mempertahankan anggota lama diturunkan menjadi 3 deskriptor yaitu: (1) anggota loyal dengan memanfaatkan layanan koperasi; (2) koperasi bermanfaat bagi anggota dan (3) terwujudnya demokratisasi dalam RAT. Deskriptor yang pertama dideskripsikan oleh 1 item pernyataan. Item selama ini saya loyal atau setia dengan memanfaatkan layanan Koppontren, sebanyak 137 responden $(42,8 \%)$ mayoritas responden menjawab setuju. Hal ini menunjukkan bahwa responden setuju, loyal atau setia dengan memanfaatkan layanan Koppontren. 
Deskriptor yang kedua ini dideskripsikan oleh 2 item pernyataan. Item selama ini keberadaan Koppontren sangat terasa manfaatnya serta item selama ini keberadaan Koppontren menjadi wahana untuk melatih mandiri dalam hal bisnis (ekonomi), masing-masing sebanyak 160 responden (50\%) dan 125 responden (39,1\%) mayoritas responden menjawab setuju. Hal ini menunjukkan bahwa responden setuju, keberadaan Koppontren sangat terasa manfaatnya serta keberadaan Koppontren menjadi wahana untuk melatih mandiri dalam hal bisnis (ekonomi).

Sedangkan deskriptor ketiga dideskripsikan oleh 1 item pernyataan yaitu item selama ini kegiatan Koppontren menjunjung tinggi demokratisasi dalam RAT, sebanyak 130 responden (40,6\%) mayoritas responden menjawab setuju. Hal ini menunjukkan bahwa responden setuju, kegiatan Koppontren menjunjung tinggi demokratisasi dalam RAT.

Indikator kemampuan menarik anggota baru diturunkan menjadi 2 deskriptor yaitu: membuat program-program baru serta mengikutsertakan anggota dalam program-program baru. Deskriptor yang pertama dideskripsikan oleh 2 item pernyataan. Item selama ini Koppontren aktif membuat program-program untuk menarik anggota baru, sebanyak 114 responden (35,6\%) mayoritas responden menjawab setuju. Hal ini menunjukkan bahwa responden setuju, Koppontren aktif membuat program-program untuk menarik anggota baru. Kemudian item selama ini program yang dilaksanakan oleh Koppontren direspon positif dengan masuknya anggota baru, sebanyak 117 responden (36,6\%) mayoritas responden menjawab netral. Hal ini menunjukkan bahwa mayoritas anggota bersikap netral terhadap item pernyataan ini.

Sedangkan deskriptor ketiga dideskripsikan oleh 1 item pernyataan, yakni selama ini saya selalu ikut serta dalam menyukseskan program penambahan anggota baru di Koppontren saya dengan responden sebanyak 117 (36,6\%) dan mayoritas responden menjawab netral. Hal ini menunjukkan bahwa mayoritas anggota bersikap netral terhadap item pernyataan ini.

Indikator pencapaian visi diturunkan menjadi 3 deskriptor yaitu: (1) perumusan cita-cita organisasi; (2) pemahaman cita-cita; dan (3) pelaksanaan citacita. Deskriptor pertama dideskripsikan oleh 1 item pernyataan. Item cita-cita Koppontren disusun dengan jelas, sebanyak 164 responden (51,3\%) mayoritas responden menjawab setuju. Hal ini menunjukkan bahwa responden setuju, citacita Koppontren disusun dengan jelas. 
Deskriptor kedua dideskripsikan oleh 1 item pernyataan. Item cita-cita Koppontren dapat dipahami dengan baik, sebanyak 122 responden $(38,1 \%)$ mayoritas responden menjawab setuju. Hal ini menunjukkan bahwa responden setuju, citacita Koppontren dapat dipahami dengan baik.

Sedangkan deskriptor ketiga dideskripsikan oleh 2 item pernyataan. Item citacita Koppontren dapat dilaksanakan dengan baik, sebanyak 116 responden (36,3\%) mayoritas responden menjawab netral. Hal ini menunjukkan bahwa mayoritas anggota bersikap netral terhadap item pernyataan ini. Kemudian item cita-cita Koppontren dapat membangun wirausaha baru (mis.: ternak jangkrik, konveksi, pembibitan ikan, dll), sebanyak 147 responden $(45,9 \%)$ mayoritas responden menjawab setuju. Hal ini menunjukkan bahwa responden setuju, cita-cita Koppontren dapat membangun wirausaha baru (mis.: ternak jangkrik, konveksi, pembibitan ikan, dll).

Indikator pencapaian misi diturunkan menjadi 3 deskriptor yaitu: (1) kesempatan anggota dalam memperoleh pendidikan, pelatihan dan penyuluhan; (2) rencana pengembangan dan (3) proses pengambilan keputusan. Deskriptor pertama dideskripsikan oleh 3 item pernyataan. Item selama ini Koppontren memberikan kesempatan memperoleh pendidikan kepada anggota secara merata, item selama ini Koppontren memberikan kesempatan memperoleh pelatihan kepada anggota secara merata serta item selama ini Koppontren memberikan kesempatan memperoleh penyuluhan kepada anggota secara merata, masing-masing sebanyak 151 responden (47,2\%), 129 responden (40,3\%) dan 118 responden (36,9\%) mayoritas responden menjawab setuju. Hal ini menunjukkan bahwa responden setuju, Koppontren memberikan kesempatan memperoleh pendidikan kepada anggota secara merata, Koppontren memberikan kesempatan memperoleh pelatihan kepada anggota secara merata serta Koppontren memberikan kesempatan memperoleh penyuluhan kepada anggota secara merata.

Deskriptor kedua dideskripsikan oleh 4 item pernyataan. Item selama ini Koppontren memiliki rencana pengembangan untuk jangka pendek, item selama ini rencana jangka pendek Koppontren mudah dipahami, item selama ini Koppontren memiliki rencana pengembangan untuk jangka panjang serta item selama ini rencana jangka panjang Koppontren mudah dipahami, masing-masing sebanyak 118 responden (36,9\%), 120 responden (37,5\%), 127 responden $(39,7 \%)$ dan 114 responden $(35,6 \%)$ mayoritas responden menjawab setuju. Hal ini menunjukkan bahwa responden setuju, Koppontren memiliki rencana pengembangan untuk jangka pendek, rencana jangka pendek Koppontren mudah 
dipahami, Koppontren memiliki rencana pengembangan untuk jangka panjang serta rencana jangka panjang Koppontren mudah dipahami.

Sedangkan deskriptor ketiga dideskripsikan oleh 2 item pernyataan. Item selama ini proses pengambilan keputusan manajemen dilakukan secara partisipatif dan item selama ini proses pengambilan keputusan manajemen dilakukan secara demokratis, sebanyak 130 responden $(40,6 \%)$ dan 146 responden $(45,6 \%)$ mayoritas responden menjawab setuju. Hal ini menunjukkan bahwa responden setuju, proses pengambilan keputusan manajemen dilakukan secara partisipatif dan proses pengambilan keputusan manajemen dilakukan secara demokratis.

\section{Pengaruh Modernitas Kyai terhadap Pendidikan Kewirausahaan dalam Bentuk Kinerja Koppontren}

Berdasar hasil penelitian memberikan keputusan adanya pengaruh positif dan signifikan dari konstruk modernitas Kyai ke konstruk kinerja Koppontren. Pengaruh positif dan signifikan variabel modernitas Kyai ini memberikan penjelasan bahwa, sebagai guru, pengasuh, dan sekaligus sebagai pemimpin di Pontren tempat bernaungnya Koppontren, peran Kyai tidak bisa diabaikan begitu saja. Hal ini tidak terlepas dari berbagai macam corak dan keragaman Pontren. Berdasar 35 Koppontren yang diteliti menunjukkan, jenis Pontren di Kabupaten Tulungagung adalah Pontren kholaf dan 1 Pontren yang modern. Artinya 97\% Kyai Pontren masih sangat dominan dalam menentukan arah kebijakan organisasi-organisasi yang berada di dalam Pontren. Berbeda halnya dengan Pontren modern, dimana proses pendelegasian wewenang umumnya berjalan dengan baik.

Dominasi Kyai Pontren diharapkan dapat berperan mendukung keberhasilan Koppontren dengan memposisikan diri sebagai pengawas atau sebagai penasehat, sehingga diharapkan ada kontrol internal yang efektif terhadap pengelolaan organisasi dan usaha koperasi yang akan dibentuk.

Kyai adalah pemimpin Pontren, dimana keberadaannya tidak saja menjadi panutan santri bahkan dihormati oleh masyarakat di sekitar Pontren. Hasil penelitian ini juga menunjukkan bahwa 35 Pontren yang diamati memiliki lembaga pendidikan baik formal maupun nonformal. Lembaga pendidikan ini sangat potensial menjadi media untuk melakukan perubahan sebagaimana dikemukakan oleh Inkeles dan Smith $^{12}$ bahwa, pembangunan sosial dan ekonomi tidak akan berhasil kecuali

12 Alex Inkeles dan D.H. Smith, Becoming Modern, ..., hal. 18. 
masyarakat memiliki sikap modern, nilai dan kepercayaan kerja, kualitas hidup, dan kemampuan modern yang mengendalikan lingkungannya yang disebut dengan modernitas.

Perubahan sebagaimana yang dimaksudkan oleh Inkeles dan Smith dimaksudkan untuk mencapai keberhasilan dalam pembangunan sosial dan ekonomi, khususnya di lingkungan Pontren melalui pendidikan wirausaha dalam bentuk Koppontren. Sedangkan untuk merespon perubahan tersebut diperlukan sikap, nilai dan kepercayaan kerja, kualitas hidup serta kemampuan untuk mengendalikan lingkungan. Sikap, nilai dan kepercayaan kerja serta kualitas hidup ini semakin efektif jika diawali dari pemimpin Pontren yaitu Kyai.

Posisi sentral Kyai di Pontren dan Koppontren ini bukan berarti bahwa Koppontren berdiri atas instruksi Kyai (Top Down), tetapi yang perlu digarisbawahi adalah, keberhasilan Koppontren tidak terlepas dari peran Kyai yang memposisikan diri sebagai pengawas atau sebagai penasehat, sehingga diharapkan ada kontrol internal yang efektif terhadap pengelolaan organisasi dan usaha Koppontren.

Sebagai contoh KUK (Koperasi Unit Keluarga) La Tansa. Koperasi ini sudah ada di beberapa kota besar di Indonesia. Basuki ${ }^{13}$ mengemukakan bahwa, Pondok Modern Darussalam Gontor mempunyai kekuatan dalam bidang pendanaan yang bersumber dari kekuatan lembaga itu sendiri. Kekuatan inilah yang menjadikan Pondok Modern Darussalam Gontor mampu menghadapi hedonisme kultural. Inilah salah satu cermin "Jiwa Berdikari” yang dirumuskan oleh pimpinan Pontren sebagai jiwa Pondok Modern Darussalam Gontor. Dengan jiwa berdikari (self help), Pondok Modern Gontor sebagai lembaga pendidikan tidak menyandarkan kehidupannya kepada bantuan dan belas kasihan orang lain, tetapi kekuatan tersebut dibangun dari kekuatan lembaga sendiri dengan membangun kekuatan ekonomi seperti dengan mendirikan KUK La Tansa yang ada di beberapa kota besar di Indonesia.

Jadi jika menginginkan kinerja Koppontren meningkat, yaitu: mampu memenuhi kebutuhan anggota, mampu memuaskan anggota terhadap produk dan pelayanan, mampu mempertahankan anggota lama, mampu menarik anggota baru serta mampu dalam mencapai visi dan misi, diperlukan ketauladanan Kyai dalam bersikap, bekerja dan mampu mengendalikan lingkungan.

13 Basuki, Pesantren, Tasawuf ..., hal. 69. 


\section{E. Penutup}

Modernitas yang ditunjukkan dengan sikap Kyai yang memiliki beberapa ciri modernitas individu di atas, mampu meningkatkan kinerja Koppontren dalam pemenuhan kebutuhan anggota, kepuasan anggota terhadap produk dan pelayanan, kemampuan mempertahankan anggota lama, kemampuan menarik anggota baru, pencapaian visi serta pencapaian misi. Kesimpulan ini mengandung makna bahwa, jika Kyai memiliki sikap dan melakukan kegiatan-kegiatan yang mengarah kepada kemajuan, apakah untuk kemaslahatan dirinya (modernitas individu) ataupun untuk kemaslahatan orang lain termasuk juga Koppontren, maka keberadaan Koppontren bisa dinikmati oleh anggota.

\section{DAFTAR PUSTAKA}

Bakhri, M.S. 2004. Kebangkitan Ekonomi Syariah di Pesantren: Belajar dari Pengalaman Sidogiri, Jakarta: Cipta Pustaka Utama.

Basuki, 2006. Pesantren, Tasawuf dan Hedonisme Kultural (Studi Kasus di Pondok Modern Darussalam Gontor) dalam Quo Vadis Islamic Studies in Indonesia? (Current Trends and Future Challenges), Jakarta: DIKTIS Departemen Agama RI.

Dehaene, M. 2002. "Survey and assimilation of a modernist narrative in urbanism", The Journal of Architecture. Vol.7 No.1, (Spring).

Fikriyati, Umi Najikhah. 2009. Tradisi Pesantren Ditengah Perubahan Sosial (Studi Kasus Pada Pondok Pesantren Al-Munawwir Krapyak Yogyakarta), Penelitian, Yogyakarta: UIN Sunan Kalijaga.

Giddens, Anthony. 2002. Modernity and Self Identity, dikutip dari http:// www.theory.org.uk/giddens4.htm, accessed 6 Maret 2008.

Inkeles, Alex dan D.H. Smith, 1974. Becoming Modern, Cambridge: Harvard University Press.

Iskandar, M.S.B. 2004. Tradisionalitas dan Modernitas Tipologi Arsitektur Masjid, DIMENSI TEKNIK ARSITEKTUR. Vol. 32, No. 2, Desember, Surabaya: Universitas Kristen Petra.

Madjid, Nurcholis. 1997. Bilik-Bilik Pesantren Sebuah Potret Perjalanan, Jakarta: Paramadina. 
Sahlawi. 2006. Pondok Pesantren dan Perubahan Sosial (Strategi Adaptasi Pondok Pesantren Sidogiri dalam Menghadapi Perubahan Sosial), Tesis, Surabaya: Universitas Airlangga.

Tjakrawerdaja, Subiakto. 1996. "Kebijaksanaan pengembangan dan pembinaan koperasi pondok pesantren”, Suara Pembaruan Online, dikutip dari http:/ /www.hamline.edu/apakabar/basisdata/1996/11/08/0010.html, accessed 7 Desember 2007.

Wahid, Abdurrahman. 2004. Memahami Peran Budaya Pesantren, dikutip dari HTTP://WWW.PONDOKPESANTREN. NET/PONPREN/INDEX.PHP?OPTION=COM_ CONTENT\&TASK=VIEW\&ID=51, accessed 16 Maret 2008. 